
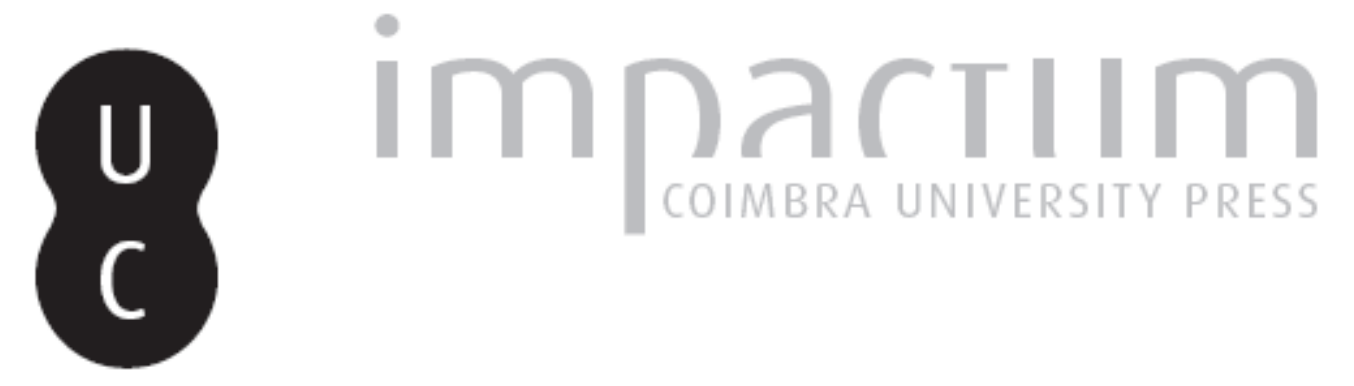

\title{
Sílvio Lima, ou o retorno do recalcado
}

\section{Autor(es): $\quad$ Carvalho, Paulo Archer de}
Publicado por: Faculdade de Letras da Universidade de Coimbra, Instituto de Estudos Filosóficos

URL persistente:

URI:http://hdl.handle.net/10316.2/29613

DOI:

DOI:http://dx.doi.org/10.14195/0872-0851_39_8

Accessed : $\quad$ 26-Apr-2023 13:19:30

A navegação consulta e descarregamento dos títulos inseridos nas Bibliotecas Digitais UC Digitalis, UC Pombalina e UC Impactum, pressupõem a aceitação plena e sem reservas dos Termos e Condições de Uso destas Bibliotecas Digitais, disponíveis em https://digitalis.uc.pt/pt-pt/termos.

Conforme exposto nos referidos Termos e Condições de Uso, o descarregamento de títulos de acesso restrito requer uma licença válida de autorização devendo o utilizador aceder ao(s) documento(s) a partir de um endereço de IP da instituição detentora da supramencionada licença.

Ao utilizador é apenas permitido o descarregamento para uso pessoal, pelo que o emprego do(s) título(s) descarregado(s) para outro fim, designadamente comercial, carece de autorização do respetivo autor ou editor da obra.

Na medida em que todas as obras da UC Digitalis se encontram protegidas pelo Código do Direito de Autor e Direitos Conexos e demais legislação aplicável, toda a cópia, parcial ou total, deste documento, nos casos em que é legalmente admitida, deverá conter ou fazer-se acompanhar por este aviso. 


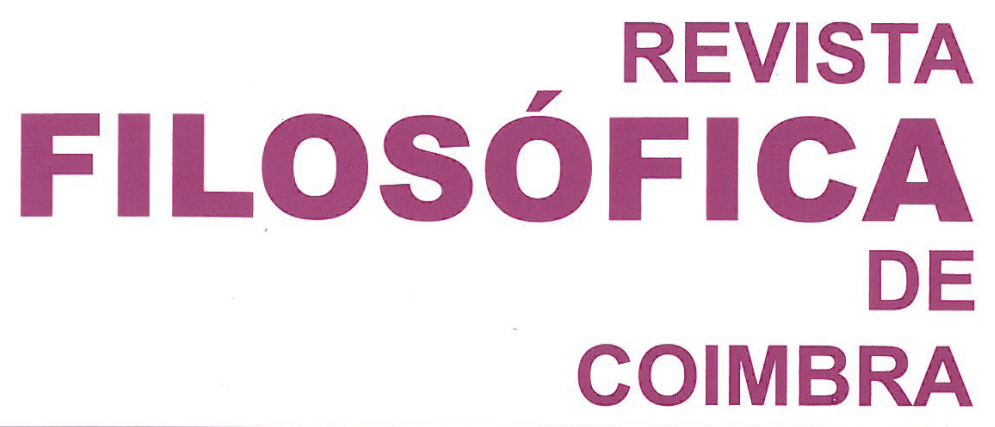

vol. 20 - número 39 - março 2011

vol. 20 - número 39 - março 2011

Fundação Eng. António de Almeida

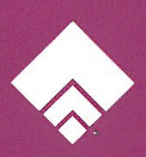




\section{SÍLVIO LIMA, OU O RETORNO DO RECALCADO}

PAULO ARCHER DE CARVALHO*

Resumo: Apreender a vis epistémica de Sílvio Lima (1904-1993) para a Filosofia é o escopo do artigo. O professor universitário em Coimbra, expulso e diminuído pelo Estado Novo, sondando as «filosofias do sujeito», na linha neokantiana de Joaquim de Carvalho (e de Brunschvicg ou Cassirer) - e da heurística historiográfica - funda na ética da compreensão da alteridade, em nome da racionalidade ôntica, a crítica à extensão da psicanálise freudiana o que, noutro plano, o leva a desenvolver uma concepção ontológica da temporalidade e da historicidade (Dilthey, Scheler), à revelia da verdade «demonstrada» ou «revelada». Distanciando-se decisivamente do positivismo e de cartilhas «científicas», o ensaísmo será a via aberta para o pensamento filosófico.

Palavras-chave: ensino da filosofia (Coimbra); filosofia do sujeito; racionalismo; idealismo crítico; ética; psicologia compreensiva; ensaísmo; teoria da história - historiologia; repressão ideológica.

Summary: This article aims at grasping Silvio Lima's (1904-1993) epistemic "vis" concerning philosophy. Professor at the University of Coimbra, he was expelled and diminished by the Estado Novo, when probing and sounding out the 'philosophies of the subject, Joaquim de Carvalho's (and Brunschvicg's or

* Investigador acolhido no Ceis20 (UC), bolseiro post doct. da FCT.

O texto, e a conferência que o originou, A Filosofia na Faculdade de Letras de Coimbra (1911-1957) - num dos painéis do Ciclo Comemorativo do Centenário da Faculdade, a 25-XI-2010 - foi elaborado a partir da dissertação do autor, Sílvio Lima. Um místico da razão crítica (Da incondicionalidade do Amor Intellectualis), Coimbra, fotocop., FLUC, 2009, para cujos desenvolvimentos e bibliografia remete, poupando o leitor à demasia dos utensílios críticos e documentais, que ali encontra. Entre parêntesis assinalam-se [OC] as Obras Completas de Sílvio LimA, Lisboa, Fundação Calouste Gulbenkian, 2002, (ed. José FERREIRA DA SILVA). 
Cassirer's) neo-Kantian line, as well as the heuristics of the historiography. By deep understanding the ethics of otherness in the name of an ontic rationality, he criticizes Freudian psychoanalysis, leading him to develop an ontological conception of temporality and historicity (Dilthey, Scheler), in defiance of 'demonstrated' or 'revealed' truth. By distancing himself from positivism and from scientific booklets, he will prefer the writing of essays as a bridge to philosophical thought.

Keywords: teaching of philosophy (Coimbra); philosophy of the subject; rationalism, critical idealism, ethics, comprehensive psychology, essays, theory of history - Historiology; ideological repression.

A humanidade nunca se adquire na solidão; também nunca é o resultado de uma obra confiada ao público. Só a alcança aquele que expõe a sua vida e a sua pessoa aos «riscos da vida pública»

HANNAH ARENDT, homenagem a K. Jaspers, in Essays in Understanding. 1930-1954.

\section{Antes da Filosofia alcançar uma condição filosófica}

A profanação, anunciada por um sector do Liberalismo em 1823 e tentada na greve geral académica de 1907, atingirá na Alta o «santuário das ciências e das letras», como a cidade de Coimbra se faz representar há séculos. A velha senhora, a queirosiana Alma mater dos bacharéis, na qual Rafael Bordalo, lendo Antero, pressagiou a extinta luz, perdia o monopólio dos saberes, dessacralizados agora: a Lei da República de 22 de Março de 1911, cria novas Universidades (Lisboa e Porto), pedras do mais vasto programa laicizador e modernizador que expulsa o Deus histórico dos Católicos, moribundo no criacionismo teológico, da semiótica e do paradigma universitários. Elucidativo é o preâmbulo da lei, passe-se a citar: "porque a grande razão política das revoluções incide nas transformações sociais em que estas importam" e tal como "a Revolução Francesa destruiu as instituições de ensino herdadas da sociedade católica", "assim a revolução portuguesa de 5 de Outubro tem o dever de reformar os diversos ramos do ensino para chamar a Nação ao exercício da democracia". Abolidos os juramentos religiosos, o foro académico, o hábito talar no espaço público (tornando-se facultativa a capa e batina), interdita-se o ensino da religião nas escolas estatais e do Direito Eclesiástico na faculdade jurídica, "atendendo [a] que as ciências entraram definitivamente no período de emancipação de todos os elementos estranhos à razão". 
A Constituição Universitária de 19 de Abril de 1911 - publicada na véspera da Lei da Separação - autentica o fim da Faculdade de Teologia e estatui, em sua substituição, a de Letras, exigência mesma que os teólogos desde a década de 1880 arvoravam. O mercado dos licenciados sentenciava o fim da Teologia: em 1910, para 12 lentes, subempreitados alguns noutras tarefas, apenas 20 alunos totalizavam os $\mathrm{V}$ anos do curso. E, em 1911, inscrevem-se 21 aprendizes no I ano de Letras: mas o trend de crescimento irá superar, em meados de 1990, a fasquia dos 4.000 na totalidade dos seus cursos.

Prelectores da nova Faculdade serão, por regra, os prelectores da antiga: os ex-teólogos António Ribeiro de Vasconcelos, Joaquim Mendes dos Remédios, Oliveira Guimarães, Joaquim Alves dos Santos, Francisco Martins (falecido em aula, em 1916), Porfírio António da Silva. Os mais velhos ou enfermos (Jesus Lino, Araújo e Gama, Bernardo Madureira, Joaquim Alves da Hora e Silva Ramos) inscritos como professores, não o serão; o camoniano José Maria Rodrigues, ingressa na congénere lisboeta. Novidade é a primeira mulher numa cátedra portuguesa, Carolina Michaëllis, que renuncia a Lisboa, demasiado distante da casa tripeira, e opta por descer do comboio na cidade do Mondego, literalmente, no pequeno mundo. Os lentes, mais conservadores que liberais, rejubilam com o sábio consórcio e envolvem-na num "círculo fervoroso de admiradores", escreve A. Vasconcelos.

Em 1912, projectam-se muros para a nova ideia, acabados um quarto de século depois, com infindáveis suspensões de estaleiros e orçamentos. Nada se vê hoje pois a Faculdade foi canhoneada pelos arquitectos a mando do Estado Novo: o sarcófago jaz murado no actual bunker da Biblioteca Geral. Em 1951, surgira já este outro do qual agora se escreve, caixa-forte para o ilusório exílio da ignorância do mundo.

Aos poucos, um estranho termo do idealismo alemão, Weltanschauung, ouve-se na Faculdade de inspiração francesa que, ao espartilhar as Ciências (históricas, filosóficas e geográficas) das Filologias (clássica, românica, germânica), mais impõe a matriz histórica e subalterniza a Filosofia, por sua vez, como sombra tutelar e vigilante da Psicologia. Com efeito, o curso filosófico, atulhado de história e opções filológicas, apenas dispõe de duas cadeiras de «filosofia pura» (Lógica e Moral) e três de História da Filosofia (Antiga, Medieval e Moderna, depois, Moderna e Contemporânea). Casos notáveis: novos saberes humanísticos (como a Antropologia cultural) são omitidos, à excepção da Psicologia (Geral e Experimental); e ciências sociais emergentes, mormente a Sociologia, a comtiana mãe dos saberes, não constam do currículo (será circunscrita nos preâmbulos e decretos secularizadores). Em Etnologia, na lição racista de Eusébio Tamagnini, lê-se o struggle for life ao contrário, life for struggle, que lhe irá prover 
a base teórica nacional-sindicalista. Em suma, universitários de Coimbra habitam o poder em Lisboa e este insta nos universitários; não nas universidades. Ruída, com o Liberalismo, grande parte do velho poder hierocrático e do poder simbólico de que era depositária, na República impugnava-se não só o resquício «sacralizado» mas o capital simbólico civil, signos e competências científicas dos arcanos Estudos. Em plena Constituinte (1911), face à desordem exaltada da Falange Demagógica, ateneu estudantil anarco-republicano de acção imprevista e directa liderado por Aurélio Quintanilha, um deputado exige o fecho definitivo da Universidade. O lobbism coimbrão, a bem dizer, a maioria dos eleitos, bacharéis pela casa dionisina, seguindo António José de Almeida, Afonso Costa ou Sidónio Pais, obsta ao matricídio da alma Mater.

Se as Letras são a grande novidade, também o é o ensino superior da Filosofia. No séc. XIX, ninguém, dado a pensar, abdicara de denunciar essa pobreza pátria da civilidade (instrução, educação: edução e indução) especulativa e filosófica: Silvestre Pinheiro Ferreira, Alexandre Herculano, Antero de Quental, Amorim Viana, Sampaio Bruno, Adolfo Coelho. Ao longo de cento e sessenta anos, na pombalina Faculdade de Filosofia, só por equívoco coubera a filosofia propriamente dita: Lógica Racional das Ciências, pouco mais. «Filosofia» designava sobretudo, na época, a raiz iluminada da investigação científica e o espírito enciclopédico e daí o enorme ruído que a enunciação Aufklärer do termo provoca entre nós. É certo que a reforma de 1772 introduzira nos estudos jurídicos textos e obras filosóficas de Christian Wolf, Antonio Genovesi, Heinécio e iuspolíticas de Puffendorf, Grócio, Martini, Bachio: mas a viradeira, vulgata da torrente antipombalina de teor formalista e anti-racional que se segue, com o degredo político de Sebastião José de Carvalho, arrastando ao lento esquecimento as suas reformas, aos poucos exilara o ensino filosófico como propedêutica menor (contra a corrente persiste Rodrigues de Brito); e com a extinção do Colégio das Artes (em 1834-36), sumir-se-ia quase num século o estudo das Humanidades em Coimbra, apesar de aí a Filosofia se ter mantido na situação de pobre e encavacado parente da História (Cronologia, Cronística) e mero rudimento literário ou teológico. A promessa da regeneração Liberal saldou-se, neste campo, numa evidente ambiguidade: mesmo após a reforma de Passos Manuel, no segundo terço do séc. XIX, a filosofia continua a confinar-se à propedêutica jurídica; e em meados do século o kantismo, por via de comentadores, dará lugar, na década de 1860-70, ao krausismo e sociologismo, mais acentuando a feição instrumental ou pragmática do pensamento político. Confinada aos estudos da legalidade das coisas, das relações interpessoais e da legitimação do monopólio da violência do Estado, o ensino da Filosofia mais interessava à aprendizagem da Ordem e da disciplina estatal; e a 
alguma retórica excedentária ou dialéctica discursiva que serviria o alforge dos «homens públicos», do que à inutilidade especulativa (universo de difuso pragmatismo onde melhor habita) e ao ócio teórico. Pouco mais valia, no mercado local da instrução, estudar em si o pensamento, ou pensar por si o estudo. Regra geral, e Antero bem sopesou o estado da arte na década de 1860, o sistema universitário desinteressara-se de ensinar a pensar - melhor, na inigualável expressão francesa, mâitre à penser - como ocorre na rotineira avaliação social do desempenho muito centrada na testificação cognitiva desligando-o da praxis criadora e do fazer saber. Se a avalanche cientista, prospecto anti-escolástico (escolástica reformada, dirá Joaquim de Carvalho), que o positivismo acarreta no final do século não soterrou, ao contrário, a tentação teórica, mais afundou, contudo, a metafísica (não a da, póstuma, reabilitação heideggeriana) no campo dos saberes dispensáveis, ou impugnando mesmo a sua validade como «saber».

Não é difícil entender como, em 1911, a Filosofia - que, na lição kantiana do Conflito das Faculdades, sintetiza a verdadeira vocação incondicional dos saberes universitários (ao acolhermos a leitura «libertária» de Derrida) -, ficou emparedada entre o historicismo, de matriz positivista e o eruditismo tradicionalista ou, melhor, ficou refém do conflito entre Fé e Razão, arquitectado por uma ontologia primária que incomunica crença e descrença, refechando as fenomenologias da convicção em cubículos cativos dos respectivos apóstolos. Se o cientismo decretara a óbito da filosofia, mera «teoria do conhecimento» ou enciclopédia geral das ciências, a meditação incondicional, hipótese metafísica, é estrangulada a duas mãos: à destra teológica, pela dogmática criacionista e o neotomismo categorial reforçado no concílio Vaticano I; à sinistra teleológica, pelo perfectibilismo, paradoxo extrapolado da Filosofia Zoológica de Lamarck que o monismo determinista aduz na ontogénese e filogénese do Ser. A fenda epistémica que a filosofia instala no intervalo da temporalidade, de que falará Martin Heidegger naquele seu idioma inventado; a filosofia, o corte que cria para (se) poder pensar, comprimia-se entre o evolucionismo de $\mathrm{H}$. Spencer e o continuismo físico-matemático naturalista, a metafisiofobia do tempo, dirá Adolfo Coelho. Doutro lado, submetia-se ao continuismo bíblico de conteúdo providencial ou ainda apocalíptico - dando azo teórico a essa fobia dos teólogos de aprisionarem um Ignoto Deo, às suas próprias ignorância e certeza conjunturais, como denunciara Friedrich Nietzsche na trans-lúcida Genealogia da Moral. Por isso, a filosofia teve de questionar o seu próprio métier e o método para topar com a porta de saída: a gnosiologia. A este respeito escreverá Eduardo Lourenço. "A meio caminho entre uma metafísica inviável e uma doutrina que é a morte da filosofia depara-se-nos sem grande surpresa 
o triunfo da teoria do conhecimento, ressurreição kantiana permitindo a coexistência de um conhecimento científico com uma reflexão sobre esse conhecimento" 1 . Seria essa modalidade de reflexão que, resistente ao positivismo hegemónico, contumaz contra o providencialismo, assinalaria na cultura filosófica nas Universidades a matriz heurística daquela «filosofia dos professores de filosofia», como bem percebeu Schopenhauer.

Acresce que, em 1911, não são claros os sinais da revolução científica que Mach, Poincaré, Max Planck, abrem a um Albert Einstein devorado pela infinita paixão teórica do mundo. A tese de Leonardo Coimbra, rumor da teoria da relatividade restrita, é vencida em Lisboa em 1912 - no mesmo concurso que nega à universitas a liberdade neokantiana e evasiva de António Sérgio. O universo a partir do qual e sobre o qual os filósofos pensam - com as enormes excepções da intempestiva nietzschiana, da durée de Bergson, ou, depois, da epopeia da ontologia negativa da outridade, do Pessoa poetósofo, contemporâneo mesmo de Heidegger, que não ousam furar a cultura académica - assenta ainda na superstição dos pretensos números pitagóricos ou da geometria euclidiana e estribase em concepções newtonianas do espaço e do tempo, subjugadas pelas ideias da homogeneidade e continuidade estrutural da matéria, servidas por regras cartesianas do pensar, inversamente inferidas, tornando analógica a normatividade da res extensa à res cogitans.

Degradada a velha antinomia essencialista entre os seres e as coisas, no século (afinal, sob esta perspectiva, verosimilmente nosso) que, no pico do inumano, do atmoterror e de Auschwitz (nomeados por Sloterdijk e Arendt), trata os seres como coisas (res nullius) e as coisas como seres, ou próprios deuses, venerados há pouco na liturgia cumulativa dos templos hipermercantis, antes da queda na bancarrota da memória que deles se reconstruiu. Como o cósmico axioma da incerteza de Heisenberg, a lógica triádica e probabilística, o teorema da incompletude de Kurt Gödel, são projectos impensáveis ou estariam na forja do silêncio; assim se pensava o kosmos ainda belo relógio ao qual o relojoeiro universal de Leibniz (mesmo sem relojoeiro) dera corda e se sustentara, abandonado, em sensata e quasiterna melodia finalista.

Neste quadro, não admira que a Filosofia se embale no giro pendular, ardil bipolar gerado entre pólos que mutuamente se admitem, por se excluírem, e consolidam nessa troca de sinergias e negantropias simbólicas (e eminentemente práticas, a avaliar pelos ganhos das brancas e pretas no jogo-de-xadrez de Maniqueu). Explicação prática (e didascálica) dessa bipolaridade será, contra as sebentas de História de Filosofia Medieval e

${ }^{1}$ Eduardo Lourenço DE FARIA, «Situação do Existencialismo», III, Revista Filosófica, ano IV, 12. ${ }^{\circ}, \mathrm{XII}-1954,233$. 
de História da religião, a edição, em 1915, dos Elementos de Filosofia Científica, de Alves dos Santos, cujo imprimitur laico assinala a inicial marca de água do ensino filosófico em Coimbra. Estranha hoje, após as leituras de Nietzsche e Heidegger (que doutro modo lemos, pedindo os óculos emprestados a Deleuze, Foucault ou Ricoeur), a exegese da noesis e da poiesis com o rigor mortis das mathemata e das ciências exactas, tal como na época instituidora se entendiam. Cartilha do positivismo empirocriticista e evolucionista, o texto cifra-se na récita escolar e assertiva do q. e. d.: "a filosofia é a sistematização (.) das conclusões certas (.) a que chega a ciência experimental" testando um "ensaio de explicação universal"'2.

Um obstáculo na curva da via: ao objectar-se a didáctica da bíblia científica contra a Bíblia da revelação, emperra-se no impasse. Indague-se se é filosofia. Com razoabilidade responde-se negativamente; é profissão de fé, dilação do apostolado sectário na aparência de o não ser. Joaquim de Carvalho confirma-o no texto dedicado ao que considerava o "último representante em Portugal do positivismo" e à sua fundamentação "estreita" da filosofia ${ }^{3}$. Alves dos Santos não fora só mais um adesivo da República; idolatrava a crença dominante, qual fosse: a 1 de Fevereiro de 1909, deputado monárquico, faz o Requiem de D. Carlos na missa do sufrágio; a 5 de Outubro exulta com a revolução e horas depois é secretário do presidente do Governo Provisório da República, Teófilo Braga. Na tese de 1900, o «teólogo» refuta evolucionismo e monismo, tentando salvar a alma que, afinal, não entende; após 1910, o «filósofo» abraça monismo e evolucionismo, na mais radical versão empirocriticista, com a fé nova do converso arranca-almas. Porém, pelo caminho, cingido às fontes psicopedagógicas e ao método experimental teorizado por $\mathrm{Cl}$. Bernard, funda em 1912 o Laboratório de Psicologia Experimental, pequena revolução possibilitada pela reforma republicana, cuja informação empírica continua por analisar - em torno da «congenitude do ser português», da pedologia e da estesiometria - e que no plano prático merecera a atenção de Éd. Claparède, psicólogo que pessoalmente conheceu no decurso de uma «missão científica» a Genebra, reflexo de uma nova atitude de actualização cultural e científica que desde os finais do séc. XIX se desenha e que a República melhor acentua.

Precocemente morto em 1924, a Psicologia é interinamente regida por Maximino Correia, pedido de empréstimo à Medicina, não sem que,

${ }^{2}$ Alves dos SAntos, Elementos de Filosofia Scientifica, Coimbra, Moura Marques, 1915, pp. VII e 10-12.

3 Johquim de Carvalho, Obra Completa, VIII, Lisboa, F. Calouste Gulbenkian, 1996, p. 85. 
entretanto, em 1928, irrompa enorme polémica pública em torno da preterição do antigo assistente Manuel Serras Pereira para a vacatura da área. A anterior dissertação de doutoramento que este apresentara, A tese escolástica do composto humano, em 1923, é de uma desusada obscuridade: sem lá por os pés, quer um laboratório da Psicologia para inferir, acudindo à filosofia perene, a existência de Deus, abonando a vocação substancialista. Contra o psicologismo fisiopositivista dos primórdios (que A. dos Santos seguira em assonância com Th. Ribot), tentava agora o reverso animismo escolástico que continuava a ser, na precisa definição de Joaquim de Carvalho (seguindo Brunschvicg) a imposição de uma ortodoxia. Mas tese e propositura, após aprovação, foram rejeitadas pela Faculdade: o arguente que lhe propusera nota máxima, Oliveira Guimarães, era o mesmo que causticava agora Serras Pereira.

Seria Ś́lvio Vieira Mendes Lima, em 1929, o primeiro doutorado no país na área da Psicologia Experimental, não in nomine mas em plena pertença, preparado e orientado, porém, na escola franco-suíça por Éd. Claparède e sob a influência de $\mathrm{H}$. Antipoff, numa época em que um jovem J. Piaget, em íntima correlação com a lição e a metodologia destes, inicia a publicação dos primeiros resultados da sua investigação, depois reenunciada como «psicologia genética». E desde logo Lima o introduz e comenta entre nós, patenteando a sede da contemporaneidade e da co-relatividade dos saberes e o esforço de contínua actualização que o distinguem numa Universidade de rotineira cultura escolar - cuja denúncia da medíocre autolatria, sacralização institucional de si mesma, levará, também em 1935, à expulsão de Aurélio Quintanilha - que mais ritualizava a «solidez» das soluções e num Tempo que mais lhe apetecia adormentar, sem refutações, no conforto das soluções «totais» e «absolutas». Será no diálogo com o tempo teórico e com a opacidade do tempo histórico que viveu que se evidencia o esforço modernizador de Lima.

Inviável seria aqui, na perspectiva da economia argumentativa e expositiva, analisar a teia complexa de problemas que abordou. Elegem-se assim três instâncias capitais da escrita filosófica: o rasgo na luta pela liberdade de filosofar e a opção pelas filosofias da liberdade, na senda e em íntima articulação com o plano crítico que Joaquim de Carvalho ideara; a reflexão ética que desenvolveu de modo mais profundo e elaborado; e a memória e a temporalidade como objectos teóricos da actividade filosófica. Em nota final, apenas breve referência ao processo político-universitário da sua expulsão e posterior recalque institucional, que será esmiuçado em próximo artigo na Biblos, a revista duma Faculdade e Universidade que Sílvio Lima desinteressada e sacrificialmente serviu como poucos, no século $\mathrm{XX}$, e na qual resistiu uma das mentes mais incómodas, inconformistas e brilhantes. Esse o motivo pelo qual a sua inteligência, readaptação 
activa, "processo mental, suscitado por um defeito de desadaptação" na síntese do mestre Claparède, o levará a sondar cada vez mais fundo o microcosmo humano, "a sombra que marcha diante de nós, inatingível" (OC, II, 1454-55). Mas perante a "situação», o nacional-situacionismo, a sua desadaptação (que assumia sem introspectivos autismos) irá até ao ádito cívico e pessoal da resiliência.

\section{Tarefa prioritária: a libertas philosophandi, utensílio de si própria}

No trilho de dupla insurreição filosófica, ferrete maiêutico do parto, contra a doxa dos dogmas revelados e o paradoxo de demonstradas convicções, Joaquim de Carvalho é o autêntico marco do ensino e do estudo da Filosofia e da História das Ideias na faculdade de Coimbra, até meados da década de '50. Alves dos Santos tivera o mérito de convidar, em 1916, este jurista e ex-aluno excepcional da primeira fornada da licenciatura de Letras, para assistente de Filosofia moderna e contemporânea, no que seria secundado na propositura por Mendes dos Remédios, o cronista dos judeus que denuncia a "história da intolerância" pátria (Biblos, I,1925), vulto influente na vida Universitária na ascensão e queda da I República.

Não é despiciendo este dado. Carvalho lavra discreto orgulho da raiz talmúdica. Questionado por uma escritora judeofrancesa, o próprio aclara a sua origem duma "vieille et pieuse famille d'apothicaires de Tomar". Ressalta a tensão entre antagónicas tradições religiosas: a cabalística pedra filosofal dos «boticários», messianismo de um deus vizinho cultivado por um povo "prisioneiro da esperança», que o levará a indagar a concepção intelectual da Deidade no Judaísmo; e a contrária tradição dogmática da ortodoxia católica. Mas é improvável, ao invés do que nota Jean-Javal na década de '30, que Joaquim de Carvalho se visse «católico liberal», embora educado nesse ambiente religioso. É a obra e vida do Judeu Spinoza, a libertas philosophandi e sua filosofia da liberdade, que the vale a mais esclarecida exposição na literatura crítica portuguesa. E sobre Judeus que escreve alguns dos melhores textos: Leão Hebreu e Isaac Abrevenel, Abrãao Zacuto, Uriel da Costa, Pedro Nunes, Ribeiro dos Santos. Neles tenta descortinar o ethos, uma razão prática, ou filosofia prática (no sentido descrito por Deleuze) no pensamento judaico.

É a duplicidade espiritual, detectada no problema de uma história da consciência perspectivada na diacronia da conversão marrana que o move. Dado o «passado socrático-platonizante», na síntese de Lima (OC, II, 1564), Carvalho elege racionalismo e relativismo para refutar o Système positivista, na linha neokantiana de Baden (Windelband, Rickert, E. Lask, B. Bauch) e Marburg (Hermann Cohen, Natorp, E. Cassirer) e 
da filosofia da imanência de Schuppe - não para repelir a positividade e indagação historiográfica da filosofia, ou ao arrepio das noções evolução da physis e de progresso humano. O estudo da filosofia alemã leva-o ao encontro da Fenomenologia na década de '40, interpretando Husserl na linha do idealismo transcendental, com a rectificação empírica de Max Scheler, que lhe assinala o apriorismo material na ida até às coisas para, nessa deslocação, formular as esferas dos valores e testar a descrição fenomenológica do puro domínio do vivido que ensaia na leitura da Saudade. E à fenomenologia pede a épochê para a emocional intelecção da «alma nacional», que o republicano histórico e independente cultiva como pátria de afectos e de linguajares - mas não, como o culturalismo o fez de modo superlativo e impositivo, na lógica da assimilação «imperial».

Ora, no trilho neokantiano, após Hermann Lotze e o System der Philosophie, Joaquim de Carvalho cindia o elemento poético religioso do princípio especulativo, não validando assim a Moraltheologie - essa peregrinação do povo de Deus rumo à República moral universal da qual a divindade não se evadira, pois dela sendo constituinte, era o esteio último da sua constituição - na ampulheta de Königsberg, acertando antes os ponteiros seculares pelo desencantamento do mundo (Weber) que ele próprio prefere enunciar como desdivinização. No primeiro meio século de vida da Faculdade, J. de Carvalho (1892-1958) é o vulto incontornável e central do ensino e da investigação historiográfica da Filosofia em conexão com a publicação e estudo das fontes, clássicas, europeias, portuguesas da história das ideias (na Biblioteca Filosófica que funda em 1947, prosseguida a pedido da editora Atlântida por Sílvio Lima após 1958). Para muitos dos seus pares, também dentre os mais esclarecidos daqueles que se lhe opõem no campo ideológico, ele é o sábio, à maneira heurística e erudita. Exemplo maior do clerc universitário que não dobra face aos ataques pessoalmente conduzidos, sob a capa utilitária e «política», do ditador que, passo a passo, lhe vai extorquindo o seu munus: primeiro, retira-o da direcção da Biblioteca Geral (que acumulava com o secretariado de O Instituto); depois, em Agosto de 1934, extingue a «sua» Imprensa da Universidade, tal o sorites qualitativo e quantitativo que aí desenvolveu, em amplas colecções historiográficas, filosóficas e literárias; por fim, em Maio de 1935, retira-lhe o auxiliar dilecto, Sílvio Lima, cuja expulsão Carvalho continua a denunciar, num silêncio acusador; ao inviabilizar qualquer assédio ao lugar vazio, vendo como suprema indignidade quem o queira preencher (como Delfim Santos sem êxito fez). Também a ditadura degrada o lugar reflexivo quando se senta nas cátedras, definitivamente por 1950, a estirpe nacionalista e integralista que não só não questiona o autêntico ambiente de repressão filosófica, como, nos casos mais notórios, o nutre. Por fim, o ditador destrói o derradeiro vestígio do cenário que 
lhe seduzia a respiração e o pensar: despacha a demolição do casario e passadiços da Alta onde o diálogo peripatético com os discípulos, ou o passeio solitário e reflexivo de Carvalho, melhor se cumpriram.

É Joaquim de Carvalho - no auto-retrato, filósofo pobretana - quem escora a permanência da Faculdade de Letras, em 1919, encerrada pelo ministro Leonardo Coimbra que, em oculto conluio com Alves dos Santos, logo desmantelado, mantém o plano depois ganho de criar a Faculdade de Letras do Porto, espécie de arquétipo do paraíso catedrático onde docentes licenciados se doutoram por decreto, plano no qual a filosofia, afinal, fora mero pre-texto para um projecto político e pessoal precariamente atingido; é o republicano Carvalho quem exige, num dos acumes de conflitualidade da guerra religiosa, contra a recusa do governo jacobino, que o seu colega, o historiador padre Gonçalves Cerejeira, ingresse na docência por exclusivo mérito; é ainda Carvalho quem ensina, e põe em prática a quem o ouvir, o sábio apólogo nietzschiano da filosofia: o ofício do filósofo é ser protestante. Ele marca a agenda internacional: secretário da Societas Spinoziana, de Haia, estabelece e reforça permutas intelectuais com Léon Brunschvicg, Roger Bastide, Carl Gebhardt, Marcel Bataillon, Keyserling, Cruz Costa - por vezes indo pela rede de prestígio que nos salões e nas universidades latinas goza o poeta simbolista Eugénio de Castro, par nas Letras desde 1914. E Carvalho quem sustém, com Cabral de Moncada, na década de 1950, o ingénuo frenesi da filosofia portuguesa em nome da pascaliana, racional, dignidade do espírito, ao exigir uma filosofia sem pátria se não a universal mátria especulativa e indagadora, mas sem recusar, no contrapólo, o estudo sistemático das fontes filosóficas, literárias, historiográficas ou bibliográficas da cultura portuguesa, num vasto projecto sapiencial ao qual desde 1917 metera ombros e que não prescindia do rasgo hermenêutico (e do método filológico bebido em Carolina Michaëllis) para se executar e para indagar a historicidade das ideias, também científicas e filosóficas.

Em suma: se, ao negar-lhe a pura abstracção, em tese desaconselha o voo ensaístico e «impressionista», não deixa de abrir consistentes caminhos - pela imediação que mantém com António Sérgio, que quer atrair a Coimbra após o exílio deste - aos jovens que revelem particular pendor para a escrita ensaística e ele mesmo acabará por testar sobre Teixeira de Pascoais, o Zaratrusta do Marão por si nomeado, ilações que não cabem em filosofias prefabricadas. Essa liberdade (e idoneidade) de pensar e investigar deixará vis epistémica fecunda que outras gerações abraçarão, como, nas leituras maiores, Sílvio Lima, no ensaísmo exploratório de temáticas de intensa novidade e actualidade; como Agostinho da Silva (1906-1994), na primeira fase sondando o ensaísmo de Montaigne, ou inteligindo o sentido do Amor e da Deidade na cultura helénica, ou, depois, 
em vivas peregrinações ensaísticas de um, palavras suas, vagabundo filósofo, profeta do alvorecer humano, entre Sócrates, o Grego, e Cristo, o Judeu, anunciando boas novas pelos púlpitos que são ruas e margens-sem-poder das cidades por onde caminha; como E. Lourenço (n. 1923), o cantor do Signo, no ensaísmo filosófico, não raro trazendo relatos da altura das águias - basta invocar em Heterodoxia I (1949) o uso dialógico notável do jovem assistente entretecendo, em «Situação do Existencialismo» (1954), as filosofias da Existenz com as fontes, sobretudo a hegeliana, do Idealismo e com Kierkegaard des-acossado pelo temor mas não pelo tremor -; e, na vertente mais próxima do pensamento universitário, como F. Catroga (n. 1945), na compacta historiografia das ideias - na anteriana ou no republicanismo, por vezes no colóquio justo com o Mestre que só em texto conheceu e em cuja méthys heurística (mas numa hermenêutica mais alargada) avançou, ligando os ensinamentos de J. S. da Silva Dias, cujas obras capitais, nas décadas de 1960-70, na viragem para o entendimento democrático da pólis, não são alheias ao influxo decisivo das leituras do Figueirense.

Não se afasta assim desta tarefa capital Sílvio Lima (1904-1993), ao exigir a liberdade como a essencial condição da Filosofia e seu último corolário: relê o programa crítico do regresso à filosofia do sujeito e daí extrai as consequências; ele é o case study do intelectual em activa rebelião contra o meio de clausura filosófica e as teologias da intolerância que o salazarismo propicia $-i$. e, nutre, delas se nutrindo, como o pelicano, a ave mítica que de si alimenta as crias e cevara sonhos da Reacção integralista. Sob o signo de inquieta liberdade e novidade, Lima introduziu os grandes temas e autores numa Faculdade que, sobretudo no chão filosófico, desde o início da década de 1930, viu agravado o muito apertado numerus clausus, reabilitando-se o extemporâneo Index prohibitorum como norma universitária que abomina as expressões da liberdade de pensar e investigar. Ensaísta, de matiz sergiano, lançou os textos pioneiros de antropologia e sociologia do desporto e teorizou o ensaísmo (Ensaio sobre a essência do ensaio, 1944), tentando dar-lhe uma filosofia que o habitus do autor dos Ensaios carecia: o ensaísmo será ao longo da obra a coerente working-hypothesis $(O C, I I, 1576)$ duma abordagem compreensiva. Em Teoria da História, discutiu Hegel e Marx e impugnou, em nome da historiologia, as filosofias da história ou historiosofias, desconstruindo panlogismo, necessitarismo e determinismo como visões metahistóricas, também mesmo nas versões de matriz providencialista - sobretudo da filosofia perene -, das quais eram recíprocos e contrários sucedâneos. Nisto tudo lutou contra a opacidade (e a concretude) dos muros que cerravam a Filosofia num lugar inabitável. Autor da pioneira recepção crítica à psicanálise, omissão capital que impugna recente tese (Imprensa da Universidade: 
2010) que sobre o tema exclusivamente versou, contestou signos hoje moribundos de Freud (Sexualmonismus, panlibidismo, nos aspectos mais decisivos) antecipando críticas de Lacan, não inscrito ainda no horizonte; e validando Jung e K. Jaspers e, sobretudo, o complexo paradigma compreensivista - com o ínsito apelo aos saberes transdisciplinares numa epistemologia aberta, sem perder o rigor conceptual, a iniciar pela história do conhecimento; e intenta superar essa espécie de apartheid analítico que consumiu os eruditos ao longo de séculos, e consome, e lhes deu duros salários a ganhar, em vão compartimentando conhecimentos em tipologias e espartilhando-os dos sujeitos que os fazem e os entendem, como se, extrínsecas verdades reveladas pelo grande panfleto do universo, fossem imposições da evidência e não achamentos de novas dúvidas na navegação científica, poética, filosófica do Liber Mundi - ou de outras artes semióticas de arresto singularmente aparelhadas para interrogar a submersão profunda do pensamento.

Assim, em 1935 publicou Sílvio Lima a hermenêutica minuciosa e arrojada sobre a tensão entre o Amor e Misticismo, e sobre a essência amorosa do mito, dialogando com Max Scheler e Freud, em excertos algures próximos daqueles que, duas década depois, G. Bataille iria expor (embora alheio de todo ao misticismo ateu que Sartre denunciaria no autor L'Erotisme). Para defender o "imperativo categórico do respeito do direito das minorias" (OC, II, 1472) discutiu, em 1946, norma e anormalidade sem dúvida a partir dos textos de Georges Canguilhem, pai teórico, na história das ciências e na epistemologia, da normatividade que M. Foucault usará como fulcro da rica, agitadora, pesquisa arqueológica e genealógica dos conceitos que coabitam na historicidade das regras de viver, $i$. e., que (se) fazem história. Na década de 1950 inicia um diálogo longos anos sem resposta - tal sucedera já com a tese doutoral, O Problema da Recognição (1928) e com o Amor Místico, a tese maior -, sobre inteligência artificial e cibernética, desconstruindo a ingénua crença numa qualquer acrítica redenção tecnológica do mundo, lendo-a antes como ilusório lógos desprovido de consciência, o que é dizer, de autoconsciência, e nu de valores, manipulável, como o são os resultados factíveis apresentados como verdade suprema ou postulados por lógicas de ininteligível acessibilidade. E, sobre Platão, como se verá, irá reler a agostiniana teoria do Tempo, encontrando significantes demasiado extensos para não encerrar numa fórmula.

Mas se os encontros com o Erlebnis de Wihelm Dilthey e o vitalismo de Guyau auguram as filosofias da existência, na via do que se entendia então por Lebensphilosophie, impedem, no mesmo instante, S. Lima de acoitar a síntese do vivido como arquitectónica temporal do mundo, continuando amarrado ao conceptualismo da Razão Iluminada, miscigenado, contundo, 
em páginas únicas (na genuína e coerente respiração humana que delas exala), pelo neofranciscanismo ético que Antero inculcou na República das Letras e que António Sérgio e os seareiros releram (dentre os quais Lima se contou enquanto militante estudantil e poeta provisório e, depois, apóstolo sénior estreitando a amizade com o patriarca da Rua do Moinho de Vento). Por tudo isto, a prioritária meditação sobre a condição humana não lhe será estranha. Quando escrever, por exemplo, modelares apólogos do livre pacifismo em colóquio fraterno (1936) com um Raul Proença submerso pela Dor (do ente, também de uma pátria em gente que em si lhe produzia dor), reconduz o problema da difícil liberdade, na lição espinosiana - retomada por Emm. Lévinas e, numa versão kantiana (e livre) de um Heidegger que pessoalmente não o era, por H. Arendt para o núcleo duro da tarefa especulativa. Só a liberdade do cogito (por vezes amassada na biografia do ser pensante, indesligáveis, como no caso flagrante de Lima; ao invés do reitor de Friburgo, sós e desgarrados, parece, cada um para seu lado, o inimputável homenzinho empregado nazi, e o seu extra-ordinário pensamento), possibilita a eidética, sem a qual inútil será exigir quaisquer outros esclarecimentos à Filosofia, embora filósofos de todos os tempos, aqueles visionários das prisões, tenham excomungado a liberdade (dos outros) em Leviatãs imprescindíveis à (in)felicidade comum. Mormente se a liberdade se depara com o estadode-necessidade, como é o caso português, socialmente emparedada (na sua historicidade) entre o arame farpado, o cimento normativo da coação integral e leis avulsas do estado de sítio e de excepção civil, cuja incivilidade paulatinamente se metamorfoseou em regra constitucional e «normalidade». Também o viver habitualmente submergiu o filosofar em inusual hábito de gente que pensa.

Republicano, democrata, liberal, intimamente homem livre, sem avenças ou sinecuras a quem preste contas, e sem quotizações para ser livre, a modesta tarefa, o que parecerá aos distraídos de hoje uma modesta tarefa, a que Sílvio Lima se entregou foi a de exigir a liberdade das filosofias e a de construir excertos - escritos e vividos, intensos e belos, entrecruzados no sendo - para uma filosofia da liberdade que Antero de Quental prenunciou num opúsculo inacabado e apenas esboçara sem poder fisicamente concluir. Contudo, alguns consideram-no agora «filósofo sem filosofia». Mas haverá tarefa filosófica mais árdua do que a autoexigência escrita e instante da liberdade, o livre curso pelo estóico e budista, cristão e hindu, «caminho do meio»? E de exigir, no estrito respeito dialógico pela diferença e pela divergência, a liberdade na Ágora, em cada lição, não apenas para si (como fazem os de si mesmos deslumbrados) mas como regra política da vida, como pacto para a existência. Caído o termo em desgraça na pólis, há nele uma honestidade pessoal e intransmissível - a 
republicana virtu - que se con-funde com a corajosa coerência e molda as palavras pensadas com o barro do vivido. Bem se sabe que honestidade, palavra lenta, não faz parte do vocabulário filosófico dos atreitos ao rápido deglutir do ernestismo (de Wilde) no banquete. Ingenuum (diz-se do ex-escravo liberto) e eckleitikós (o que escolhe), avançou Lima sem redes de protecção ou refúgio anunciando o clarear do dia. Ora, na tempestade da noite, não era o Sturm und Drang mas a cegueira para muitos interminável, entre dois fogos, foi alvo demasiado fácil para os que se acoitavam por detrás das portas do poder; e, até, para os que, barricados na adversidade, criticavam as suas concepções pactuais, «burguesas»e tolerantes da Cidade.

O animus liber dos Modernos, que Kepler anunciara, parecer-lhe-á a Sílvio Lima o essencial da condição filosófica, o que é dizer aqui, interrogação (não-saber) fundamental que inaugura (é Descartes quem o adestra) a condição humana. Este o seu Norte do Futuro, na funda expressão de W. Benjamin, local (in)provável para onde correm (donde ocorrem) as ideias: por isso, só o ingresso numa filosofia do sujeito (individuum, o indiviso mínimo de cada filamento fragmentado pela vida) permitiria içar âncoras para uma viagem epistemológica que autorizasse a dialogia interdisciplinar, em articulação, não unitária nem disjuntiva, com os diversos campos do saber, polarizados pelos estudos humanísticos - nosológicos - e pelas ciências da vida. Só objectivando esse plano poderia o filósofo reconstituir a racionalidade duma visão ôntica do ser e devolver-lhe a autenticidade da vocação especulativa. Em parte, explica-se por que procede à exaustiva hermenêutica, em sede Psicológica, da freudiana dominância libidinal e impulsional, que lhe parecera (consciente) racionalização de um irracional determinismo (inconsciente), tentando impugná-la para reaver a claridade kantiana e reingressar no platónico eidon, o mundo das ideias claras e concisas e o da «pura consciência», no qual, doutro lado anota criticamente a Kant, o filósofo das três Críticas não atendeu à perturbação emocional e à «mancha afectiva» do parto racional, isto é, ao que hoje se pode designar por uma razão pática ou sim-pática. Por isso, de todas as «psicologias da profundidade» é a releitura de Jung que acolhe na pluralidade fenomenológica da mente, pois este evitou, "a despeito da pressão e compressão ideológicas exercidas - de todos os quadrantes - pelos entusiastas «ortodoxos» e «heterodoxos» das várias escolas psicanalíticas, reduzir arbitrariamente a complexa alma do homem (como os esquemas genéricos são fáceis, cómodos e reconfortantes!) a um «sistema rígido e imutável» dominado por um só e mesmo instinto" $(O C, I I, 1584)$.

O necessitarismo, o que «realmente foi, é ou será», das explicações sistémicas, tal como se perfila a freudiana, de inicial base positivista 
e, depois, de grelha e de tipologia oclusa, perturba a claridade da libertas philosophandi, introduzindo disfunções e ruídos, a cuja exegese urge proceder em sede psicológica, desembargando a filosofia de o fazer. Também o autor de Matière et Mémoire (embora se tenha embaraçado Lima, na análise psicológica, com as «duas memórias» de H. Bergson) lhe parece truncar no intelecto o "libérrimo direito de urdir" e no intelectual o direito de livremente o expor na praça pública (cf. $O C, I I, 1570)$. Situou-se Sílvio Lima nessa difícil fissura, e ele mesmo contribui para a escavar, entre a psicologia e a filosofia, sendo discutível, ao contrário do que o notável discípulo Miguel Baptista Pereira sugeriu, que fosse unicamente «psicólogo». Lima foi-o, sim, pioneiro e inovador na primeira metade do século XX em Portugal de uma psicologia hermenêutica, como a caracterizou, mas foi-o para desimpedir o caminho à filosofia (mens) demasiado obstruída pelos recalcamentos da Sexualtrieb e inimputabilizada pelas novas apetências omniscientes das explicações originárias do Reino do inconsciente. Não negou o Eros que invade e inaugura o corpo, claro, e a mente abarca; mas divisou nesta a reciprocidade de Anteros, não a derrota e a subjugação do inteligível pelo ininteligível. Ora, a despeito da legalidade da razão, numa visão anti-autoritária da filosofia, de certo modo sincrética e acrática (talvez, na desambiguação, incrática), como é a sua (a Filosofia não é resposta a coisa fenomenal alguma, é a pergunta do ser ou, em versão errante, a pergunta pelo ser), Lima diligenciou afastar a insciente, essa sim, morte do Sujeito às mãos desumanizadas da normatividade do sistema e da impessoalidade (in-existência) das lógicas impositivas. Esse o significado manifesto (e latente) do seu ensaísmo na reversão do paradigma, numa época, construída e destruída nas crateras das duas guerras mundiais, que mais decretava a morte da Razão (não só em Buchenwald, ou em páginas queimadas dos jornais mas, «cientificamente», em universidades e faculdades de filosofia) e a razão, moribunda, aturdida pelo Horror, mais carecia de quem, pensando, a socorresse. O decisivo alanco refundado nas últimas décadas do século $\mathrm{XX}$, premindo releituras do idealismo, mormente na matriz universalista de Kant, na perspectiva locoglobal da intelecção, inclusão e aprofundamento da liberdade e da íngreme empreitada da democratização do mundo, hoje fazem casos de estudo as teses do recalcado professor de Coimbra (se não repousa, e os últimos ruídos do silêncio são disso reveladores, oculto ainda nos arcazes da Universidade). 


\section{A Ética: gramática constitutiva da historicidade do sujeito}

É certo que Joaquim de Carvalho lera no Tratado teológico-político de Espinosa o manual teórico da liberdade de pensamento no contexto da história da filosofia europeia e, na esteira de Brunschvicg, da Ética deduzia a demonstração do progresso da inteligência correlata do progresso da autoconsciência e do ethos da liberdade, em conexão com o ensinamento de Kant para quem a ética é a "ciência da liberdade». De facto, o campo no qual o debate filosófico secularizador teve origem e foi mais relevante, situa-se no domínio da discussão ética, mormente no capítulo da secularização do ideal de tolerância e na edificação do conceito e da prática de tolerância civil e religiosa. Os contributos de Locke, Kant e Bayle no capítulo da defesa da «tolerância civil», foram determinantes, na esteira de Marsílio Ficino ou Nicolau de Cusa e sobretudo de Espinosa, embora se refiram a eticidades diferenciadas. Locke no termo assinala como intolerável político o ateísmo e o «papismo» (catolicismo) no modo em que poderiam perturbar, corrompendo os costumes, a prossecução de um «bem comum civil»; Bayle, partindo duma perspectiva que acolhia a liberdade de consciência autónoma da dogmatização teológica, escritura o apólogo duma moral racional de acordo com a qual todos os entes, incluindo apóstatas e sem fé, se submetem aos ditames racionais («instinto da razão») da busca da verdade e da virtude e impugnando o unanimismo da fé como condição formal e suficiente da busca da unidade civil na organização da Cidade. Mas Lima, recolhendo esses contributos, melhor ligou essa visão ao ser essente de Parménides; ao devir universal da vida (Heraclito) na sua diversidade, pluralidade e mobilidade - o reconhecimento da pluralidade das «formas de vida», as Lebensformen (Spranger), contra organicismos e holismos, é a sua regra de ouro ética com evidentes consequências epistemológicas -; ao axioma da razão persuasiva e compreensiva que tenta articular, com a Modernidade, o empírico real e a ideação de um telos perfectível que o Humanismo e as Luzes apostaram decifrar. A liberas voluntas da lição espinosiana - inscrita no paradoxo de uma liberdade determinada e autoexigida - é mediada pela espontaneidade de Epicuro, refractada no atento estudo sobre J.-M. Guyau (Esquisse d'une morale sans obligation ni sanction, 1885) que Lima elabora em 1927 (Ensaio sobre a ética de Guyau) no qual apreende a inequação entre determinação, autodeterminação e contingência (Boutroux), o aleatório e o desconhecido que continua a habitar o coração dos seres e das coisas. Porém, identificar as zonas sombrias do desconhecido não significa com ele pactuar, numa entrega sem termos, ou contra ele se dar a um combate sem tréguas: cabe ao filósofo tentar interpretar sub specie aeternitatis a mensagem autolibertadora do espírito, ou seja, o movimento a que aspira 
o entendimento mesmo da existência e do mundo, medium simbólico de se desgarrar das gaiolas da morte, não em voo instigado e transcendente para o Desconhecido, mas na imanente e metódica inclusão sua, «descida» a si que afinal não mais é do que um achamento. A lição de Antero, na revisitação hegeliana de Espinosa e do "panteísmo da razão» não será olvidada.

Posição difícil, quase insustentável num mundo crescentemente incendiado (P. Celan falará dos incêndios do tempo) pela esquizofrenia entificadora do «nada» e do "absoluto», em que se aplica o professor de filosofia em Coimbra: se refuta sobredeterminações gnosiológicas, transcendentes ou providenciais e qualquer heteronomia, maxime, de ordem escatológica, nega a infradeterminação física, mesológica ou bio-fisiológica, mesmo se escorada (e por isso mesmo) por perigosos enquadramentos de uma sociologia cega, e de insensível épica, que submerge o indivíduo numa totalidade antropológica e antropofágica, e que solicita a presciente auscultação do devir, em nome do extermínio e da perfeição da raça, da aniquilação e da luta de classes, ou de uma nova cruzada - acompanhada de trombetas marciais e de Cânticos epopeicos - para a recristianização do mundo. Ao recusar o sociologismo como explicação total, variante cientista do panlogismo, sobretudo na vertente da sociocracia prognóstica e das utopias sociais (negativamente demonstradas como distopias) - note-se, no acume mesmo das cotações sociologistas nos mercados futuros das ideias, antes da sua estrondosa bancarrota e ao não renunciar ou abstrair do irredutível histórico (Dilthey), num entendimento adogmático da Modernidade, o relativismo de Lima não cauciona acrónicas (ou ucrónicas) e exógenas demonstrações do futuro como divindades redentoras do presente. O devir é texto aberto, do qual supomos conhecer, com ténue probabilidade, as primeiras linhas e inteligir, com fraca previsibilidade, tendências (O Determinismo, o Acaso e a Previsão na História, 1943; $3^{\mathrm{a}} 1958$ ). Noutros termos, condição de validade do acesso (construção do) ao conhecer, é despistar a ilusão presciente, abjecto semiótico, da narrativa histórica. Na sua construção historiológica melhor apreenderá o sentido-nenhum dessa causação exaustiva ou moralizante - o transcendente teleológico não fundamenta o agir e o pensamento ético: Ética é método antropológico, autopropedêutica para o saber-ser, o que é dizer, autotélico.

Assim, a ética assinala, antes de mais, a via de acesso ao conhecimento do ser mas não é o conhecimento - apenas a interpelação da historicidade do próprio saber conduz à reflexão sobre a natureza, os limites e o valor do que [se] sabe por si e de si mesmo. Mas o saber exige a espinosiana espontaneidade do lógos (sponte sua), tese que seria acolhida numa analítica minuciosa por Derrida, muitos anos depois, também num regresso 
à desmedida mobilidade de Kant (e do neokantismo de H. Cohen) e à extraordinária limpidez do enunciado da humana dignitas (em convergência com as Declarações dos Direitos do Homem, editadas no transcurso da Revolução de 1789), em interpelação exímia ${ }^{4}$. Ora, se o homem é automaturgo e a si faz se animal teórico, animal de afectos, em tudo isso é, não somente o animal metafísico de Schopenhauer, mas o único animal histórico preso à situação heraclítica de um "fugidio momento do tempo, que flúi sem cessar" no amplexo da temporalidade existencial ${ }^{5}$.

A difícil correlação entre temporalidade (duração, mutação, finitude) e a «dimensão» histórica (prospectiva e perspectiva) sem a qual o ser não $e ́$, releva afinal da tensão que a razão histórica diltheyana introduz, não somente condição ontológica, mas possibilidade do trilho epistemológico dos saberes sobre o qual a ontologia se constrói. O Ser não existe fora da historicidade; mais do que na introspecção ou na psicanálise, que poderão aclarar difusas reminiscências ou biografias esquecidas, rostos egóides do inconsciente recalcados pela educação, religião, padrões culturais e normas de conduta, é na História que se revela a face dos homens. Mesmo aceitando, em parte, o enunciado do «inconsciente colectivo» de C. G. Jung, e apreendendo-o no seu tempo, na análise da ascensão fascista, por exemplo, ou na hermenêutica da irracionalidade das massas (que G. Le Bon ou Ortega y Gasset haviam proposto), o racionalista crê que é a consciência que hegemoniza e disciplina a psychê, desbestializando o Ser (pois este erigiu, interpôs socialmente, a barreira da historicidade com a Natureza - formação, progresso material, técnico e científico, novas visões especulativas ou criações artísticas, produtos quanto promotores, numa expressão tão cara depois a N. Elias, do «processo civilizacional») e o conduz ao agir histórico e à sua reflexão. Dito doutro modo: é o Sujeito jogando e jogado em complexas redes sociológicas, submergido na História (de facto, é a consciência subjectiva que a inaugura) - quem legitima a entrega da filosofia à sua vocação especulativa, e esse o postulado do qual Lima tenta reconstituir uma ontologia, não aquela realista, substancialistaentificada, fechada e categorial lida sobre Aristóteles, mas uma ontologia sem termo, aberta, autocompreensiva, que não equacionasse o fim do Ser (em nome da sua finalidade transcendente), que é, vendo bem, a mais relevante sequela das gramáticas do fim da História. Esse o fundamento do requisito interdisciplinar da episteme do corpo e da psique, enquanto comportamento sobretederminado por uma axiologia bio-psico-

${ }^{4}$ Cf. Jacques Derrida, Acabados, seguido de Kant, el Judio, el Alemán, Madrid, Trotta, Minima, 2004.

${ }^{5}$ Cf. Sílvio LIMA, «Melancólico mas não muito» (1969), mns. $f$ l. 1 - BFPCEUC, pasta «Notas Pessoais». 
sócio [-afectiva]; e para a procura do «espírito», enquanto pensamento, actividade intelectual criativa de ordem não-ficcional; e para a procura na Cidade da acção, conjunção e injunção. Mas só no cadáver vivo de Cronos as faces poliédricas do ser se anunciam e só através do pensamento se comunicam.

Ora, a perspectiva historiográfica dos saberes (e dos sistemas de crenças) apontava para a debilidade diacrónica do(s) juízo(s) de «verdade» e para a relativização do Absoluto, doutro modo, aderindo com Carvalho à lição kantiana, diferençava um conhecimento por conceitos ("teoria geral do mundo como síntese do saber") e um conhecimento construído por conceitos ("fundamentação crítica da possibilidade do próprio saber") 6 . Pelo esforço secularizador da filosofia, instaurado pela ética - não no anelo de anular ou outra vez matar o morto, o Deus-Pesssoa de Nietzsche - no momento em que esta era, de modos mais ou menos incidentais, aspirada pelas teologias da totalidade, pagaria Sílvio Lima um débito existencial demasiado elevado. "Para nós", escreve numa das conclusões da tese de licenciatura, o citado estudo sobre a "a crise moral contemporânea», Ensaio sobre a Ética de Guyau, "o problema da moral deve ser posto racionalmente, não em termos de eternidade, mas em termos de realidade e idealismo". Mas, ao comentar o filósofo francês e a liminar negação da ideia de imortalidade, rechaçando a hipótese ontológica optimista de raiz leibniziana, Lima denuncia análogo carácter dogmático da premissa do autor de L'Irréligion de l'Avenir, pois se só a fé pode tomar da imortalidade a razão demonstrativa, a sua pura negação conduziria a análoga atitude de cariz dogmático, i. e., à demonstração negativa de similar impossibilidade deíctica ou à inversão da teologia teofânica em antropofânica.

Mal e virtude não promanam directamente de sistemas de crenças e descrenças, como P. Bayle assinalou, nem dos sistemas ético-jurídicos, coactivos e sancionatórios, que neles assentam, como Guyau evidenciara, mas de uma conduta interior que avalia e atende positivamente à expectativa daquela sociedade de pessoas morais que Kant assinalara na Fundamentação da Metafísica dos Costumes (Scc. III). No indivíduo habita pois um ideal societário, a propensão «expansiva» anotada por Guyau, perto daquilo que, no final do século XX, E. Morin irá designar por «auto-ética», uma autoconsciência do limes, não tanto no sentido da afloração da «consciência moral» individual, mas como signo da consciência de si (o cuidado de si, lhe chamou Foucault, com Deleuze) desenhada fora da espiral egóide que inala (aspira / inspira) a «democracia cognitiva». Ora, essa aspiração da democracia ética (embora a ética seja cognoscente "auréola das minorias", pois poucos percorrerão o Gólgota,

${ }^{6} C f$. Johquim de Carvalho, Obra Completa, $V$, ed. cit., p. 114. 
adianta Lima) é alheia ao Reino dos fins supremos, mas não à cidade dos homens. Daí, ao incorporar com Fichte a dialéctica do eu / não eu na apreensão da sociabilidade e da racionalidade (o lógos incomunicável é uma ficção do vazio), e ao contratualizar essa dialéctica (objecto mesmo do pacto, a diversidade), integra-a como procedimento para firmar o pacto do bem comum, interiorizado, também, como realização (o agir) do bem individual. Há um momento subsuntivo em que o idealista, o asceta da vida de Scheler, ao sublimar e vencer impulsos instintivos, protagoniza o "esquecimento heróico do $e u$ " (LIMA, $O C, I, 154)$, não por qualquer predeterminada ordem ou harmonia cósmica e monadológica, mas porque desenvolve a consciente representação intelectual, de fundo estóico e ciceriano, do utilitarismo social da sua atitude (ib., 132). A expressão «utilitarismo social» não é um termo acabado, avaliamos, pois ao admitir a pluralidade dos conceitos do mundo, num «pluralismo ontológico», o utilitarismo esquece que o mundo é um só e só este. Mas tende a significar, e esse aspecto é claro, a fuga «por cima» - o que é dizer no contexto, «metafísica», subindo aos muros, andando por telhados -, ao beco sem saída da hipertrofia relativista (publicitando que todos os caminhos vão dar a Roma, indiferente é seguir por qualquer) e da atrofia do cepticismo radical (se nenhum caminho vai, ou Roma não passa duma ficção) que adensam a obscuridade frustrando uma filosofia prática da existência. Em sociedades crescentemente capitalistas, no fundo de terríveis crises de que só hoje no recôncavo se encontra a analogia, esta reexpedição da Ética para o aparente Reino da inutilidade, parecerá absurda petição inicial. Mas é a única réplica - a inutilidade ética só na utilidade do Spiritus se acha e só na comunicação (pôr-em-comum, ser-comum) se descobre - que articula para tentar delimitar o ilimitado imperium estatocrático que, desde 1917-1922, cercando a Europa, é legitimado pelas interpretações holísticas e antidemocráticas da volonté genérale; e para refazer o indivíduo, salvando-o do esmagamento, relevando o principio do dano que John Mill expôs. Não era bem a glosa do consabido tema segundo o qual só o solitário encarnará o solidário. Era antes o cambiante secularizado da ilustração cristã. Lima evidenciou a reversão dos termos: só o solidário (o que cuida do outro) ascende à condição do solitário (o que cuida de si). A sagesse, na sua proposição mais elevada.

Por isso, o neofranciscanismo ético, a dádiva ou entrega do ser, se lhe assemelhava (a partir das releituras anterianas de A. Sérgio, J. de Carvalho, R. Proença) a autêntica hipótese metafísica para o agir (também para o agir teórico e deontológico do filósofo). Mas numa cristologia secularizada, a ética adquire a dimensão estética, melhor, uma «estética da simpatia social» (B. Croce), fundindo-se na kalokagatia socrática, pois só o belo moral aspira suscitar e entender (pensar) as hipóteses metafísicas e só a 
ética esteticiza a vida. Ela é, enquanto criação e filosofia, «uma confissão de que a vida não basta», extrapolando o aforismo de Pessoa. Quer dizer, reavendo Espinosa, Lima bem atendeu a que a virtude não tem qualquer cotação pragmática, virtutis praemium ipsa virtus, paga-se a si própria; mas ao fazê-lo, e ao fundamentar a ética da responsabilidade (Weber) assente numa axiologia dos valores, expôs-se ingenuamente (livremente) ao risco de ser «julgado» (sem processo, sequer, ou julgamento) e perseguido pela autocracia, correndo um daqueles conjunturais «riscos da vida pública», sem os quais o Ser, no límpido juízo de Hannah Arendt, não conquista a sua humanidade. Pagaria ao longo da vida o preço - demasiado pesado, não só o da expulsão mas o dessa exclusão civilizada ao ser remetido na prisão-faculdade - por ser pessoalmente livre numa terra que desprezou / desaproveitou a dimensão da liberdade, como norma pública, e num Estado que a condenou como o mais hediondo crime civil. Embora na historicidade se revelem esparsas luminosidades da Ética, bem se reconhece que não é a História território seu. Nem a ética traça fronteiras históricas, fios ideológica ou politicamente imaginados, e imaginários, geometrias móveis que excluem, em cada múltiplo dos múltiplos presentes, o humanus de si mesmo, em nome da dádiva ou da herança do Passado (leia-se, o governo dos mortos comtiano) ou da tomada do Futuro (o triunfo dos porcos de Orwell bastará, não é aqui preciso pedir à História o saber processual dos meandros do terror na «passada» ilusão do futuro). A voragem do passado e do futuro roubam o genuíno nada do presente, escriturou Pessoa, oráculo das horas incertas.

\section{Tempo e Memória}

Coerente com o imo do programa filosófico, S. Lima tentou criticamente reconstituir, a partir de meados da década de 1940 prolongando-a pela década seguinte, uma teoria da história recenseada no sujeito cognoscente, operação que, na época, contra empirismo e realismos, depara nos esforços de Paul Ricoeur, Histoire et Verité (1955), a correspondente tradução e o liame à comum matriz da «tradição crítica». Esta sua situação, entre o relativismo gnosiológico e o racionalismo, insistindo no carácter precário dos resultados, eles mesmos ensaísticos, doutro modo é convergente com aqueles que, desde a década de 1930, procedem à instrução crítica do historicismo e do determinismo histórico, destituindo as demonstrações tautológicas do cientismo. Pense-se, nos exemplos maiores, em Karl Popper (The Poverty of Historicism, 1935, na versão original), em Benedetto Croce (La Storia come pensiero e come azione, 1938) e em R. G. Collingwood (An Essay on Metaphysics, 1940), que intentam, estes dois últimos, libertar 
o hegeliano Espírito das suas peias finalistas e panlógicas e o primeiro articular com uma teoria do conhecimento histórico atipológica. "Como o prudente Herculano", sintetiza neste ponto Lima a pesquisa, "repudiamos essa lógica imanente da História, seja ela de inspiração idealista à Hegel e Proudhon, ou materialista à Karl Marx; para nós ela só pode traduzir o sentido que Herculano lhe deu", ou seja, a construção teorética para uma explicação lógica a posteriori que de outro modo não se alcança (cf. $O C, I I, 1263-65)$.

Não admira, neste sentido, que tenha reencaminhado a especulação filosófica, por via gnosiológica e deontológica - apelando às virtudes dianoéticas expostas por Aristóteles (probidade, equidade, rigor) - para a apreensão histórica do tempo, constituindo largos excertos de uma episteme reconstitutiva do originário sentido da historiografia, cujo programa desde Heródoto ou Tucídides se esboçou: testemunhar (ver, histor), conhecer, compreender e narrar, revolvendo no campo mnésico (que ele próprio, historiador, revolve e abre) a existência do humano no húmus. O que for «visível» (ou interpelável) do passado, mediado por instrumentos analíticos e hermenêuticos do presente, constitui uma observação que visa constituir uma cadeia de continuidades e descontinuidades que se perdem, escreverá depois $\mathrm{M}$. de Certeau, numa multidão de vozes. $\mathrm{O}$ eco retencional, construção crítica e racional a partir de um grupo metafísico de hipóteses e cingido pelas interrogações dirigidas aos testemunhos (documenta), afasta assim as tendências redutoras, historizantes ou efabulatórias - os tradicionais géneros literários biográficos, genealógicos ou hagiográficos - bem como recusa liminarmente o facticismo positivista (aquilo que na tradição francesa se nomeou como histoire évenentielle, essa «agitação de superfície» do El Niño da historicidade). Alicerçado sobre as precauções heurísticas, o saber histórico, a interrogação ao tempo, aos homens no tempo, acolhe Lima a posição de M. Bloch, só é passível de estabelecimento se for acolhida a lição da Hermenêutica pois o facto só passa a ser histórico pela posição que ocupa na cadeia cognoscente, lógica e metodológica, utilizada pelo historiador. Por suas palavras: "Para a história positivista (que não é positiva) o facto histórico seria algo de pré-existente e de extra-existente em relação ao historiador; um dado material, concreto, espécie de coisa (daí o seu coisismo histórico) que o investigador «extrairia» do documento ou fonte: concepção esta ingenuamente empirista, ignorante de todo o labor operatório da mente do sábio" (OC, II, 1243). Ao arrepio dessas visões históricas finalistas e definitivas, ou das representações auto-suficientes da totalidade, Sílvio Lima melhor acentua o carácter construtivo, hipotético, relacional e complexo de qualquer teoria da História que se arquitecte e de qualquer narrativa à qual se tente colocar o ponto final; pois historiar (se "a História 
nunca está feita" e é transitoriedade, mutação), é reconstruir numa cadeia interpretativa novas hipóteses e reintegrá-las num perpetuum mobile $(O C$, $I I, 1258)$, incessantemente cativo, pela sua estrutural precariedade, de «reabilitações» e «revisões». Não só a história flúi no rio temporal de Heraclito; a historiografia é ela mesma fluxivel.

Noutros termos, a hipótese ontológica carece de fundamentação na episteme. $\mathrm{O}$ saber histórico abre caminho à antropologia da diversidade, i. e., a dadas (e paradoxais) perspectivas sobre os indivíduos, os grupos ou as sociedades humanas, mas não é, assertivamente, o homem, quer dizer, nela ele revela a sua situação ontológica ${ }^{7}$, porquanto, afastado da Natureza (Hegel), nela ele se supera espiritualmente (Scheler); mas não consegue afirmar quem seja, só na irredutível singularidade o afirma. Ora, se a tarefa historiográfica convoca uma actividade psicológica cuja metódica tarefa, no âmbito cognitivo e reflexivo, trabalha em analogia com a introspecção - e daí, dado o carácter abstracto do tempo, o pedagogo, na esteira de Piaget, referir o problema da sua difícil apreensão na infância - a retrospecção só se possibilita porque, em rigor, cada Ser se situa simultaneamente em diversos campos mnésicos (autobiográfico, sociológico, histórico) e se depara com a simultaneidade do campo analítico («sujeito» e «objecto»). Porém, entrado em cena, o historiador - o que acede à outridade através da endopatia - não se situa apenas nesses campos paradoxais; ele não se confronta com o seu passado, mas com o passado, um nihil ontológico. Ele especializa, através do efeito de distanciação - última virtude dianoética, não-aristotélica - o campo de observação ("horizonte histórico") e transporta-o [criva-o] criticamente para o saber histórico. Dada a decisiva ausência nomotética, a inverificabilidade de leis gerais e determinadas, conjugada com concepções não-cíclicas nem circulares do tempo, mas também não-pontuais nem linearmente cumulativas (como denuncia Sílvio Lima as leituras mecânicas ou adialécticas do progresso), é neste outro plano, o reflexivo, que a magistrae vitae ciceriana acha a sua póstuma lição: pelo estudo e conhecimento histórico, escreve, recenseando Expérience et Histoire de Max Müller, "o homem descobre ou intui, por trágica experiência vivida, a sua temporalidade" $(O C, I I$, 1580). O reconhecimento da condição humana e da historicidade da existência irão remeter o professor, no final da sua vida activa (antes de uma ansiosa depressão lhe silenciar de vez a escrita e a investigação, momento em que "todo o passado recalcado veio à tona e a minha luta, na busca da ataraxia, continua não sei até quando e até onde", escreve em 1965 a Vitorino Nemésio), para o trilho da legibilidade do «fundo ontológico» de Müller, embora se afaste coerentemente "das variações

${ }^{7}$ Cf. Sílvio Lima, Teoria da História, pol., Coimbra, s. e., s. d., (1962?), pp. 11-12. 
de fundo teológico-filosófico sobre uma respeitável posição de fé" (ib., 1582). Sobre a legibilidade ôntica lia a legalidade da razão.

Sintetizando, os estudos e a investigação histórica não se compatibilizavam com uma posição epistémica que creditasse a busca de soluções definitivas ou respostas inequívocas - embora, e nisso O. y Gasset bem chamara atenção, é a pesquisa na qual com mais acuidade se coloca o arcano da «verdade» (autenticidade probatória, testemunhal, crítica interna e externa, etc.) - é ela própria um problema, um feixe de incógnitas (Lima utiliza o termo datado, problemática) que suscita novas questões. Como se referiu, Carvalho integrava a história da filosofia num painel mais amplo e sistematizador da historiografia das ideias; numa «hermenêutica escriturária» que ele próprio, Lima, por vezes segue (OC, II, 1566), mas mobilizando o discípulo prioritariamente a historiografia conceptual em função das solicitações na malha apertada do objecto analítico e não nos grandes planos sintéticos e enquadradores, perspectiva em que o primeiro mentor os colocava. Compreende-se o móbil intelectual pelo qual, ao colocar na historicidade as filosofias do ensaísmo, do misticismo, do luxo, do desporto, ou da relação norma / anómalo, arranca da situação analítica, mais propriamente fenomenológica, e não da posição sintetizadora, $a b$ ovo, historiográfica, que caracteriza o Figueirense. Nalgum passo é perceptível a avaliação menos positiva dessa atitude patriarcal do schooler, precisamente quando debate (1948) a interpretação do mestre sobre o Fédon: "Enxudiosa de erudição crítica, a notícia do Prof. Carvalho oferece assim ao leitor uma sensação reconfortante de segurança de saber acerca de coisas inseguras de saber, como são, afinal, quase todas as teses do ideário platónico", apesar de reconhecer que à época já seria possível esquissar um núcleo doutrinal; a despeito da divergência de intérpretes e juízos, do idealismo racional e humanista (a bête noire do pós-modernismo, tão carente dele) do platonismo. Por certo, sobre a divergência, era mais vasto o campo que os solidarizava e as pontes que os ligavam ao "maior de todos os génios artísticos em prosa que a humanidade jamais leu" e à "labiríntica problemática" das dificuldades e aporias da sua obra (OC, II, 1563-68).

O diálogo prossegue quando, na leitura da agostiniana teoria do Tempo, melhor, da temporalidade, impugna em Joaquim de Carvalho as leituras dualistas - tensa e retrotensa, egofania e alofania, manifestação do eu e manifestação no eu - da Saudade (não do saudosismo, «religião» pascoasiana, «mística nacional», «filosofia» ou «arte de ser português», incorpórea «cosmocracia» que ambos deixam em silêncio), introduzindolhe um terceiro andamento - os segundos de uma eternidade, não se sabe qual - para o movimento disfónico e dialéctico protensivo que bem se adensaria agora nos conceitos de «horizonte de expectativas» ou de aspiração (ideação) do futuro que R. Koselleck e P. Ricoeur 
examinaram com invulgar mestria. Há uma tensão temporal na memória (e na reminiscência, sua parente pobre em busca de asilo) que alimenta e se alimenta do objecto saudoso, e que transporta a tentação de refruir qualquer um paraíso perdido tendendo à supressão dos obstáculos que instigam o estado saudoso, suscitando uma inadaptação (estranheza, ou, ao invés, a consciência dessa estranha inadaptação) ao presente, topografia e cronologia onde se situa o pathos saudoso e a expectativa da sua superação, o terminus da proscrição e do proscrito.

Assim, o ente saudoso aspira à superação do facto (temporal e correlacional) que impede a comparência física do «objecto», no temporalidade mesma (o presente) na qual apela à supressão (superação) da ausência - mas como, ontologicamente, esta não se pode dar no passado, nem no instante saudoso, lugar e tempo onde a "saudade-saudade" se instala, só no anelo (no Sehnsucht) do futuro (a "futuricação") o termo superador se poderia cumprir, ou, no mínimo, será essa a expectativa na qual o eu saudoso se nutre. Este enunciado só é atendível à luz da experiência agostiniana do tempo (Confissões, II e XI) e a sua dimensão triádica: presente-passado, presente presente e presente futuro, no modo como o tempo se apreende como tensão anímica para o devir e na circunstância teosófica de que o tempo nada mais seria do que uma experiência interior de si mesmo como criação de Deus. Mesmo enquanto operação teológica, essa concepção libertava a possibilidade de horizontes para a Cidade terrena, um juízo prognóstico não fundado na história mas na spes, pois também a «cidade de Deus» actua na cidade dos homens, é a civitas peregrinans em busca do «eterno domingo» ${ }^{8}$, visão de Santo Agostinho que Jaspers traduzirá num «eterno presente», instante da intuição essencial com a eternidade e o tempo, desejando-o contudo, instante, próximo, possível.

É essa intencionalidade semântica («propensão» caracterizada por Brentano-Husserl), representância (P. Ricoeur), representação suplente - característica da operação historiográfica - de um evento passado cuja reconstituição ontológica não é mais possível no instante em que se evoca porque o referente é ausente embora seja reconhecido. Noutros termos, é possível falar de representificação (F. Catroga) pois a evocação intencionalmente procura provocar uma presentificação do ausente através da sua representação. Quer dizer: ao «historiar» (rever) biograficamente o acontecido que induz o pathos saudoso, o eu saudoso estabelece reconstruções (mnésicas), representâncias (ter presente) e

${ }^{8}$ Para esta leitura: Jean Guitton, Le temps et l'éternité chez Plotin et Sain Agustin, Paris, Vrin, 1933; e Justificação do Tempo, Lisboa, União Gráfica, trad. de José BARATAMOURA, 1969, 65-77. 
representificações (dar presente) como respostas narrativas que, dada a impossibilidade radical de ocorrerem no presente instante, bloqueado, projectam-se no presente-futuro, aberto. No instante, adianta Lima, dá-se a consciência desse desfazamento, a consciência dessa consciência, por via da redução fenomenológica e da percepção interceptiva da epoché, pois esse é o tempo donde (no presente) "se dá a tensão da crise saudosa" $(O C, I I ; 1518,19)$. De resto, a saudade nada teria de intraduzível - ela é mesmo universal (E. Lourenço) - como já Carolina Michaëllis sustentara; há uma semântica do nostos (o regresso ao oikos de Ulisses), e assinala uma «doença da pátria» dos afectos, do ente que "sofre inconsolável no presente a sua ausência espacial, mas sofre porque recordando-se sempre da doce pátria na vigília e no sonho (...) anseia através de tudo regressar centripetamente a ela, enraizar-se de novo no terrunho natal" ( $i b$.). E como não se deu essa reintegração - caso em que a saudade não emergiria - esse momento só pode ser projectivo, i. e., protensivo, "resolução antecipadora" lhe chamará Ricoeur.

A tensão dramática expressa pela saudade, antes residiria numa "atitude ou comportamento vivencial de inadaptação não resignada perante $o$ presente", porquanto o eu ensimesmado, incapaz de sair de si e da retroacção da lembrança contemplativa, "debate-se como um pássaro ferido contra a muralha do presente". Este problema, sob a perspectiva psicológica já o abordara em O Problema da recognição; mas agora a madureza é mais segura e o discurso mais claro; pássaro ferido é um achado metafórico para fixar a mitologia judaico-cristã do drama bíblico de Adão que vive na ansiedade queimante do regresso ao Éden e tem saudades do céu, tal como Agostinho idealizara e por ele Espinosa zurzira em Judeus e Cristãos por dele, Céu, se esquecerem em rituais sem fundo. Na filosofia imanentista de Lima a memória e a reminiscência, o hóspede de Santo Agostinho, querem regressar. Já haviam regressado no belíssimo final plotínico (afinal, mais do que platónico), o ascenso filosófico ao princípio criativo, transfigurador, do Amor, em $O$ Amor Místico; mas agora é o pássaro peregrino quem almeja voar sobre as contingências presentes, excimesmar-se, expectante e esperançado, salvo no caso limite - a morte ou a morte da memória - no qual nenhuma representificação pode ser assegurada na existência. Nesse caso desesperado a consciência saudosa verte-se numa angustiante «soidade», sem outras perspectivas futurantes senão o encafuar no autoconsumo memorial. Nesse caso, ferido até à morte, o pássaro não consegue voar - mas não terá ainda saudades de voar?

Seria tarefa inútil apontarmos lacunas de uma obra por muitos motivos dispersa e criativamente dispersiva. Isso não faz olvidar, contudo, como seria adequado referir que lhe faltou à obra estabelecer o enunciado da junção (conjunção e disjunção), de uma teoria - não propriamente 
num termo dialéctico e sintético, mas como termo dialógico e analítico - que correlacionasse Tempo e Memória, irmanando na dialogia esses elos profundos da ida, pelo passado, até nós (através da endopatia, a compreensão da outridade). O passado, em rigor, não é nosso, nem é apropriável, nacionalizável ou privatizável, embora se reconheçam os esforços - e as investidas - que de todos os lados se fazem para ocupar essa espécie de terra-de-ninguém. Talvez porque, mais do que nenhum outro trabalhador intelectual, o historiador pensa os mortos na sua realidade como se estivessem vivos e na sua acção e pensamento (sabendo que estão mortos). Nem vale aqui especular, é sucata contrafáctica, por que o não terá feito. Pensamos que perseguiu com tenacidade na multímoda escrita um objecto que terá detectado fugazmente no «milagre grego»: a integração da "razão e o sentimento, Apolo e Diónisos, numa síntese ou totalidade harmoniosa e construtiva" (OC, II, 1578). Objecto assimptótico, sempre acossado, essa totalidade buscou-a partir de Platão, norteado no estudo do "mais espiritualmente vivo" dos filósofos da Antiguidade na perspectiva da cultura europeia, "quer como dialecta, quer como epistemologista, quer como esteta, quer como moralista" (OC, II; 1563). Mas não procurou essa totalidade nem na subjugação à Natureza nem em infradeterminação na sociedade: "sob o ponto de vista da epistemologia (...) o nosso intelecto, ao pretender mergulhar no mistério inesgotável da vida e ao forjar uma teoria interpretativa do real, por maiores que sejam os seus escrúpulos objectivantes, não deixa nunca de posicionar e de equacionar (clara ou veladamente, cedo ou tarde) o eterno problema da individualidade, em si mesmo indivisível" (ib., 1562). A busca ensaiada dessa mítica unidade perdida, milenar grandeza e miséria do humano (à escala do cosmo e à sua própria escala, animal demasiado recente, avisou J. Baudrillard) - entretanto estilhaçada pela ontologia negativa e pela pessoana experienciação do não-ser, universo de Pessoas sem gente -, seria a sua lição maior, num magistério ímpar e na actividade profissional de um pedagogo de excepcional e livre arte, que lhe valeria em gerações de aprendizes o epíteto de divino Sílvio. Professor algum, que não seja mero funcionário dos governos, ficaria impassível como ele ficou.

\section{Política do espírito: buracos no caminho de um idealista, professor de filosofia}

Porém, foi violentamente obstruída a brilhante carreira do ensaísta e do pedagogo. Sabe-se como a polémica (ainda) universitária em 1930-31, com Gonçalves Cerejeira, antigo mestre e então já cardeal, descambou na caça ao homem, embora nenhum dos tiros ad haereticum lhe acertasse: maçon, 
apoucado, exaltado, tudo serviu para exorcizar o autor de Notas críticas e a sua séria hermenêutica do autoritarismo e do dogmatismo sem freios, como o problema estrutural da intolerância que persistia numa sociedade iletrada e periférica, que fazia do subdesenvolvimento arma mesmo de arremesso de uma ideologia do «eterno retorno» contra o progresso e a democracia. Expulso por Salazar, em 1935, depois readmitido em termos incapacitantes (1942), Lima não silenciou no imo a libertas philosophandi e continuou a acusar a atimia e a repressão intelectual, concentração monológica de que falará Miguel Baptista Pereira, como o pecado original (nada original na Idade totalitária) daqueles que pensam governar o mundo, de qualquer modo e lugar, silenciando vozes, vidas, vestígios. Por certo, a política do espirito procria semioticamente a polícia do espírito. Entre os que, contra Sílvio Lima, atulhavam os ficheiros da Pide de «informações» confidenciais, alguns eram universitários, seus colegas, na dúplice situação de cordeiros e de lobos: enquanto na corporação universitária aludiam, urbi et orbi, à bondade da sua promoção e inclusão, pelo contrario, às esconsas, à polícia política sugeriam ou impunham a obstrução e exclusão. A demorada análise do processo político, com contornos universitários, instaurado a Sílvio Lima evidencia como o carácter - aspecto psicológico que, contra a corrente, o seu sendo patenteia de modo superlativo - se eclipsou como um dos valores formativos fundamentais ou objecto mesmo constitutivo do saber universitário (que é, no plano mais lato, um saber ser), ou entrou em contínua erosão como valor estimado ou cultivado in se, abissal contradição pois é no ethos que aflora e se extrema precisamente o território do agir prático e teórico de um mestre. O carácter (isso mesmo, signum, o que distingue) transforma-se, no reino da sua ausência (ou no tão mistificado borderline), em terrível handicap, desvantagem objectiva em corporações estruturadas mais sobre índices de avaliação das relações sociais, da correlação de forças, do arrolamento escatológico, da aparência ritual e da superfície burocrática das coisas e não sobre a sua fundura essente, o húmus onde a raiz do humano nasce e toma o nome e a razão. Dada a crescente mercantilização da Filosofia, arrisque-se a leitura macroeconómica da conjuntura (na ideologia universitária): Lima passou por idealista quase sem cotação no mercado local e europeu no qual era máxima a pressão deflacionária sobre o idealismo originada pela quase imparável inflação das visões aristotélicas e realistas (filosofia perene, corporativismo, marxismo).

Compreenda-se a dificuldade, inscrita na longa duração, de dicionarização filosófica do termo «idealista», o que suscita o esboço de uma narrativa ontológica. a partir do "céu estrelado sobre as nossas cabeças» que Kant admirava e Kepler contemplou. Na óptica sanchiana da vida, cujas récitas exemplares se registam com Cervantes ou Dostoievsky, 
o idealista é, no caso limite da autenticidade, um idiota: em busca do último lanço (pode ser semiótico) tropeça nas escadas mais elementares e pragmáticas do real e suas metamorfoses (nomes e coisas), qual Zenão olhando e apontando estrelas sem atender ao chão esburacado onde caiu e partiu o dedo. Mas não entende o idealista, designemo-lo aqui por professor Quixote, que não é o isolado e pragmático Sancho (o escudeiro, na caricatura classista da vida e numa antropologia primária assaz divulgada) mas o grémio corporativo dos professores Sanchos quem almeja escavar mesmo esses buracos onde Quixote cai, para que possam supor eles, Sanchos, terem avistado o que não vêem. Claro, passando uma vida profissional a gerir diuturnidades e carreiras, reuniões e papeladas e, sobretudo, na difícil empreitada de esfuracar solos, os professores Sanchos não conseguem olhar o céu ou as estrelas, normalmente com o argumento (muito consensual) de não disporem de tempo para tal (quando, no fundo, têm o tempo do mundo). Mas que interessa ?, se estão no lugar onde é suposto olhar e, não vendo estrelas (talvez, temendo vê-las), também não correm o risco de tropeçar nas valas (que eles mesmos escavaram)?

A absurda situação - dir-se-á a metonímia de uma aporia aparentemente irresolúvel - colocada a Sílvio Lima não teria epílogo. Mesmo se um ministro mais atento, tentava resolver a questão por via «administrativa», por clara pressão dalguns universitários de Coimbra (dos quais se aclaram Joaquim de Carvalho, Mário de Figueiredo, M. Lopes de Almeida, Cabral de Moncada ou Maximino Correia) perante a flagrante injustiça e as continuadas agressões em esfinge praticadas ao assumido pacifista, seria logo chamado à pedra política pela PIDE: não saberia o ministro que aquele professor (tal como Alfredo Fernandes Martins ou Paulo Quintela) nunca se poderia evadir do limbo onde fora encerrado? Graças a uma dessas «recomendações» arquivadas na Torre do Tombe sabemos hoje, pelo punho do polícia director, quem verdadeiramente, durante o Estado Novo, geria as carreiras universitárias em Coimbra: António Salazar e a sua diligente longa manus. E qual o verdadeiro móbil que, contra Sílvio Lima, tanto chagava o ditador: a velha polémica com Cerejeira em 1930-31 e a recidiva do Amor Místico. O autocrata decretara o Reino da Estupidez (que Sérgio bem caracteriza) nomeando-o embora como o da inteligência ou da política do espírito: e supondo-se o Principal, na burocracia panóptica, o mais alto cargo colegial e corporativo, a ninguém seria lícito pensar contra as suas convicções, a sua fé, muito menos um «pensador profissional» - oriundo daquela universidade onde alguns (Miranda Barbosa à cabeça) irão propor o ditador a ínclito protector. Política do espírito ou o fenómeno da multiplicação dos espelhos (a representação do universal como obsessão da mesmidade, de que falou Lévinas): ora, o que espírito exige, em todos os tempos e em todos os 
lugares, é que a instância política não o atormente, atrás ou à frente do poder económico, de uma maneira ou doutra, com guerras de sacristia, para poder ensinar, aprender, criar no seu ócio teórico (não para cumprir, a tempo e horas de entradas e saídas, o seu sono dogmático; ou para recolher abaixo-assinados e rol de confessos à causa).

É inegável a comprovação de similares dificuldades, em escala mais moderada, que, durante a I República, docentes universitários sentiram (v. g., os casos já aludidos) face a absurdas normas de "saúde pública», cuja assinatura, a de Robespierre, em parte se perpetua no salazarismo, apontando para a interferência de longa duração da instância política sobre as bases (auto)fragilizadas da autonomia universitária, pervertendo o seu significado, como será o caso mais notório do Estado Novo, quando (in)utilizar a Universidade como base orgânica do recrutamento político e instituição formativa da Ordem e da condição militante do serviço público, assim reconduzido e reduzido ao mero serviço partidário (mesmo contra os partidos) e à apologética nacional ou à missionação confessional. Lição negativa, a desse primário e remoto proselitismo dual (contra ou a favor do Abscôndito) que se inscreve numa multissecular guerra escatológica, lição à qual urge prestar a maior atenção analítica, se as lógicas da angariação e a retórica da publicidade chicana não foram combatidas como rotinas e rituais sagrados da praxis universitária. É nesta perspectiva que a obra de S. Lima e o estudo do seu atribulado processo universitário se evidencia como ponto de reflexão capital sobre os pressupostos, métodos e objectivos da inclusão / exclusão que o Estado maneja nas universidades, mantendo níveis de uma tensão ideológica - convergente com a repressão social e coacção pessoal - insustentáveis e que mais arredam e anulam os que buscam desinteressadamente o Saber, quer dizer, sem tacticismos de conjuntura e sem esses arremedos da politique d'abord que, sob cores de bandeiras políticas outras mas em análogas e duais «explicações» escatológicas, continua a calcar e atrofiar a sociedade portuguesa.

Dir-se-á que as tréguas prenunciam apenas outras batalhas. Escreveu-se que Sílvio Lima serviu como poucos a Universidade portuguesa, exigindo dela o que ela não podia dar, por constrangimentos exógenos, político-conjunturais, é certo, estruturais também, no reino do analfabetismo e da exclusão. Mas, mais relevante se torna a sua exigência: pois ela mesma, Universidade, não arcou com a responsabilidade endógena de construir a autonomia participada e hipostasiou o mérito de uma cultura da liberdade. Talvez que o persistente entendimento corporativo (arcana arma defensiva contra a intrusão dos poderes) se tenha pervertido numa abusiva e muito limitada leitura da res publica universitária, mais interessada no negócio da reprodução de saberes (e de conexões de redes sociais e de poderes públicos) do que em investir seriamente na produção do conhecimento 
e no cultivo crítico dos saberes, platonissare, no qual, pensaram os antigos, prioritariamente acharia a autenticidade. Compreende-se a cívica indignação de Lima: "A tragédia, porém, consumou-se". Um grupo de universitários no governo, comandado por um universitário, "arrastou assim a Universidade, pelo silêncio, submissão e acatamento dos «Estudos Gerais», a um verdadeiro suicídio moral colectivo". Em Maio de 1974, quando clareava uma aurora cujo rumor ouvira em místicas orações racionais, é certo que desejava Sílvio Lima sepultar esse passado "que será estudado um dia pela História crítica da cultura (ou incultura) portuguesa" $(O C, I I, 1675)$. Se, contra a pretensão de Michelet e Herculano, a de uma improvável «ressurreição integral» do passado, a História é a pergunta pela impossibilidade do sepulcro, será, no mesmo instante, a pergunta por múltiplos passados insepultos.

\section{Não é uma conclusão}

Se é útil e são que uma Escola comemore, o que é dizer, examine em comum a sua memória convocando-a, essa operação (historiográfica) desperta incómodos olvidos mantidos em letargias úteis. Vencer o esquecimento exige dupla operação mnésica, pois acolher a reminiscência, é, na bela metáfora das Confissões de Santo Agostinho, albergar o hóspede que quer voltar a casa e reconhecê-lo, derrotar a hostilidade e achar a hospitalidade.

É justo que os esquecidos refluam no exacto lugar - não na temporalidade mesma, operação historiográfica pensável mas não possível - onde eles próprios inscreveram a sua condição humana, contra o penoso e intencional desprezo daquela liberdade livre, narrada em amplos excertos por Baudelaire e António Ramos Rosa, que, afinal, alimenta na autenticidade o simpósio do espírito, compromisso ontológico fundamental para edificar, como Sísifo, a inacabada casa do ser. Mas se não ousarmos reduzir a Filosofia à Ontologia, o ser que fala à casa da fala, pela inconsequente exclusão narrativa do sujeito (que se pode diluir até, em «instância narrativa»), instaremos com Emm. Lévinas em perseguir a linguagem como porta de saída [passagem, meta-], e de emergência, à claustrofóbica entificação. Se haverá pensar, intervalo, apóstrofe nas frases vividas, é o uso objectivo da linguagem com(o) liberdade e a ôntica subjectivação da liberdade como linguagem - e se não vai nisto a pura ilusão pessoal de quem escreve, indeclinável isotopia do segma no discurso -, que incessantemente inaugura a Filosofia.

Sebal, Janeiro de 2011 